\title{
Acetate-Promoted Aldol-Type Reaction: Scope and Reactivity of Acetates and Aldehydes
}

\author{
Dong Hyeon Kim, A. F. M. Motiur Rahman, Byeong-Seon Jeong, Eung Seok Lee, and Yurngdong Jahng’
}

\author{
College of Pharmacy, Yetngnam Lniversity, Gyeongsan 712-749, Korea. ${ }^{*}$ E-mail: valingatinuackr \\ Received November 24, 2008. Accepted Febriany 11, 2009
}

\begin{abstract}
Potential of acetates and related compounds in glacial acetic acid as a cataly st for aldol-type condensation reactions was examined. Reactions of cycloalkanones or selected heteroaromatics with aldehydes in presence of $10 \mathrm{~mol} \%$ of various acetates in acetic acid afforded $\alpha, \alpha$-bis(substituted-benzylidene)cycloalkanones and substituted-benzylidene-mackinazolinones, respectively, in good yields. Annong the compounds tested, ammonium acetate is the best and effective especially towards the reactions of mackinazolinone and aliphatic aldehydes to afford 6-alkylidenemackinazolinones.
\end{abstract}

Key Wonds: Ammonium acetate. Aldol. 2,5-Bis-benzylidenecỵclopentanone. 2,6-Bis-benzylidenecyclohexanone, Mackinazolinone

\section{Introduction}

The compounds with $\alpha . \alpha^{\prime}$-bis(alkylidene)- and $\alpha . \alpha^{\prime}$-bis(arylidene)-compounds such as $\alpha . \alpha^{\prime}$-bis(benzylidene)cycloalkanones $(7)^{1}$ have been attracting much attention due to not only their intriguing biological activities such as antiangiogenic. " quinine reductase inducer. ${ }^{3}$ cytotoxic. ${ }^{4}$ and cholesterol-lowering activity, but also their potentials for nonlinear optical materials. ${ }^{6}$ They are also the important precursors for the synthesis of pyrimidine derivatives. 2,7-disubstitited tropones. ${ }^{8}$ and synthetic intermediates to functionalize $\alpha, \beta$ position during the synthesis of natural products ${ }^{g}$ and theoretically interesting carbocycles ${ }^{16}$ as well as heterocycles. ${ }^{.1}$ Arylidene-heteroaromatics have also been used to functionalize the peri-position, especially for the two-step introduction of keto group. ${ }^{13}$ and employed for the synthesis of precursors for various poly'dentate ligands ${ }^{12 e .13}$ as well as biologically interesting compounds. ${ }^{13.1 .14}$

The $\alpha . \alpha$-bis(arylidene)cycloalkanones were originally prepared from cycloalkanones and aromatic aldehydes in the presence of strong acids ${ }^{15}$ and more likely bases. ${ }^{1 \tilde{6}}$ which was named as the Claisen-Schmidt reaction. Such reactions. however, suffer from reverse and/or side reactions. ${ }^{17}$ Coordination complexes with a variety of metals have been introduced to replace acids or bases. but the yields were not satisfactory in most cases. ${ }^{18}$ Continuing efforts to find new catalysts have resulted in the introduction of various reagents such as $\mathrm{Cp}=\mathrm{ZrH}_{2}{ }^{19 \mathrm{a}} \mathrm{Cp}=\mathrm{TiPl}_{2}{ }^{196} \mathrm{BMPTO}^{19 \mathrm{c}} \mathrm{RuCl}_{3}{ }^{19 \mathrm{~d}} \mathrm{SmI}_{3}{ }^{19 \mathrm{e}} \mathrm{TiCl}_{3-}$ $\left(\mathrm{CF}_{3} \mathrm{SO}_{3}\right){ }^{1,9 \mathrm{f}} \mathrm{La}^{3+}$-immobilized organic solid. ${ }^{1,58} \mathrm{KF}-\mathrm{Al}_{2} \mathrm{O}_{3}{ }_{3}^{1,5 \mathrm{~h}}$

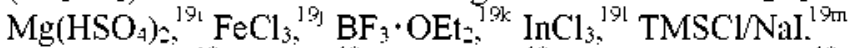
TMSCl/Pd-C. ${ }^{150} \mathrm{SOCl}_{2}{ }^{150} \mathrm{Yb}(\mathrm{OTf})_{3} .{ }^{190} \mathrm{~K}_{2} \mathrm{CO}_{3} / \mathrm{PEG}-400 .{ }^{19 \mathrm{l}}$ molecular $\mathrm{I}_{2}{ }^{19}$ and $\mathrm{Et}_{3} \mathrm{~N}$ in the presence of $\mathrm{LiClO}_{4}{ }^{19 \%}$ In addition microwave irradiation method was employed to improve yields as well as to reduce reaction time.$^{?+1}$

On the other hand, catalysts for the Claisen-Schunidt reaction of aliphatic aldehydes toward aldehydes or ketones to lead 2-alkylidene-aldedhydes or ketones are very limited. ${ }^{19 a d . d 1 . m, p}$ Even though such cases are applicable to the preparation of 2-alkylidene-aldehydes or ketones. studies revealed that these were not suitable for $\alpha . \alpha^{\prime}$-bis(alkylidene) cycloalkanones. ${ }^{21}$ Previous studies revealed that the reaction of cyclopentanone with propionaldehyde in the presence of 0.5 $\mathrm{M} \mathrm{NaOH}$ afforded 2,5-bis(ethylidene)cyclopentanone in 19\% yield ${ }^{21 a}$ while the reaction of cyclohexanone with butyraldehyde afforded 3.4-tetramethylene-2-propy lbicyclo [3.3.1]nonall-4-ol-9-one (5aa) instead of the expected 2.6-bis(butylidene)cyclohexanone (3aa) or 2-butylidenecyclohexanone $(t a a){ }^{I E}$ On the other hand, the reaction of cyclohexanone with isobutyraldehyde afforded a mixture of 2.6-bis(isobuttyidene)cyclohexanone (3ab). 2-isobutylidenecyclohexanone (4ab), and 3.4-tetramethylene-2-isopropylbicyclo-[3.3.1]nonan-4-ol-9-one (5ab). ${ }^{216}$

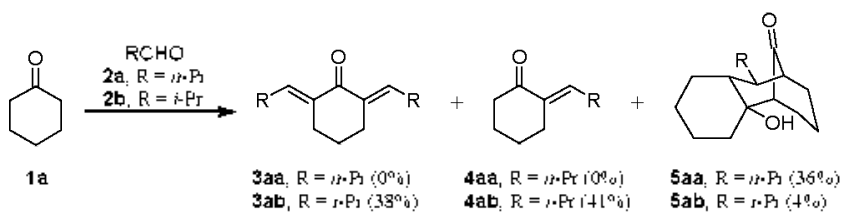

The Claisen condensation between ketones and aldehy'des or aldehydes itself, thus, have not been widely considered as a practical method because under basic conditions they often undergo self-condensation leading to complex product mistures. ${ }^{\text {a }}$ To overcome such limit. several indirect methods such as employing silyl enol ether."-2 2 -formylketone. ${ }^{3 \hat{3}}$ enamine. ${ }^{2-4}$ lithiated imine, ${ }^{25}$ and litliated enamine. ${ }^{26}$ have been designed, but sometimes long reaction sequence and expensive reagents are the bottle-necks for the general use.

Disadvantages of the present catalysts and importance of the Claisen-Schmidt reaction in synthetic organic chemistry lead us to find sodium acetate in glacial acetic acid as a new cataly'tic sy'stem for the introduction of benzylidene moiety on cycloalkanones as well as heteroaromatics. Concerning the catalytic activity of acetates in acetic acid, a couple of previous studies such as reaction of chloral with methyl ketones with sodium acetate in acetic acid to afford the corresponding aldol adduct. 1.1.1-trichloro-2-hydroxyethỵl ketones. in $41-59 \%$ 
yield. $^{28}$ and one-pot Krölunke synthesis of anuulated pyridines employed ammonium acetate/acetic acid system to generate 2.6-bis(substituted-benzylidene)cycloalkanones from (substituted)benzaldehydes to cyclic ketones have been reported. However no sy'stematic studies on the catalytic activity of acetates in the aldol condensation have been pursued as yet. We thus herein described the scope and reactivity of acetates as catalysts for aldol-type reactions.

\section{Results and Discussion}

The Claisen-Schmidt reactions of cyclohexanone (1a) with benzaldehyde (6) in the presence of $10 \mathrm{~mol} \%$ of acetates or related compounds in glacial acetic acid were first examined and results are summarized in Table 1 .

Reactions proceeded smoothly to afford 2.6-dibenzylidenecyclohexanone ( 7 ) in $83-95 \%$ yields. The reaction with ammonium acetate gave the best result which was comparable to that with sodium acetate. ${ }^{2}$ to afford the desired product in $95 \%$ yield in $8 \mathrm{~h}$ of reaction time. On the other hand, the reactions with sodium propanoate and triethylammonium acetate required $36 \mathrm{~h}$ and $72 \mathrm{~h}$. respectively. to complete the reaction (entries 4 and 3 ) and reactions with piperidinium acetate acetamide or sodium L-prolinate required even longer reaction time $(120 \mathrm{~h})$. Thus ammonium acetate can be a good candidate for the aldol-type condensation catalyst. It should be noted that the reaction in the presence of sodium L-prolinate. of which the free acid has been used as enantioselective catalyst for the Claisen-Schmidt reaction to lead $\beta$-hydroxycarbonyl compounds, ${ }^{31}$ also led bis(benzylidene)cyclohexanone in $86 \%$ yield after $120 \mathrm{~h}$. Although early study claimed that the ratios between the aldol addition product and the Claisen-Schmidt product were highly dependent on the $\mathrm{pH}$. the $\mathrm{pH}$ range was very narrow. in which the Claisen-Schmidt products were the only ones in the $\mathrm{pH}$ range of $11.0-11.4$ while the aldol adducts were the major under the $\mathrm{pH}$ range $9.8-10.5 .^{31}$ The present study showed that no trace of initial aldol-adduct. $\beta$-hy'droxycarbonyl compound 8 and/or bis- $\beta$-hydroxycarbonyl compound 9 was observed.

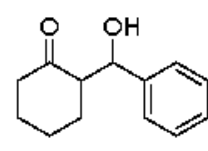

8

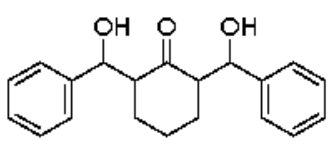

9
Effect of reaction temperature. To find an optimized reaction condition. we examined the effect of reaction temperature for the Claisen-Schmidt reaction. Although the reaction with ammonium acetate below $60^{\circ} \mathrm{C}$ required over $72 \mathrm{lh}$ reaction at $120^{\circ} \mathrm{C}$ required less than $8 \mathrm{~h}$ for the completion. Previous studies on sodium acetate ${ }^{2 ?}$ as well as present study revealed that $120^{\circ} \mathrm{C}$ can be the choice of reaction temperature. Since the $\beta$-hydroxycarbonyl compounds 8 and/or 9 are the expected intermediates. the reactions were pursued at room temperature. However, no identifiable products were isolated in each case.

Effects of aliphatic aldehydes. We. next examined the reactions of 1 with aliphatic aldehydes in the presence of ammo-
Table 1. Reactions of cyclohexanone with benzaldehyde in the presence of various additives in glacial acetic acid

\begin{tabular}{|c|c|c|c|}
\hline$\overline{\text { Entry }}$ & additive ${ }^{a}$ & time (h) & yield $(\%)^{b}$ \\
\hline 1 & ammonilum acetate & 8 & 95 \\
\hline 2 & piperidinium acetate & 120 & 90 \\
\hline 3 & triethỵlammonium acetate & 72 & 83 \\
\hline 4 & sodium propanoate & 36 & 86 \\
\hline 5 & acetamide & 120 & 84 \\
\hline 6 & sodium L-prolinate & 120 & 86 \\
\hline
\end{tabular}

"Reaction was run in the presence of 10 mol $^{0}$. additive relative to cyclohexanone. "Isolated yields which are not optimized.

Table 2. Effect of reaction temperature on the reaction of cyclohexanone (1a) with benzaldehyde (6) in the presence of various additives in glacial acetic acid

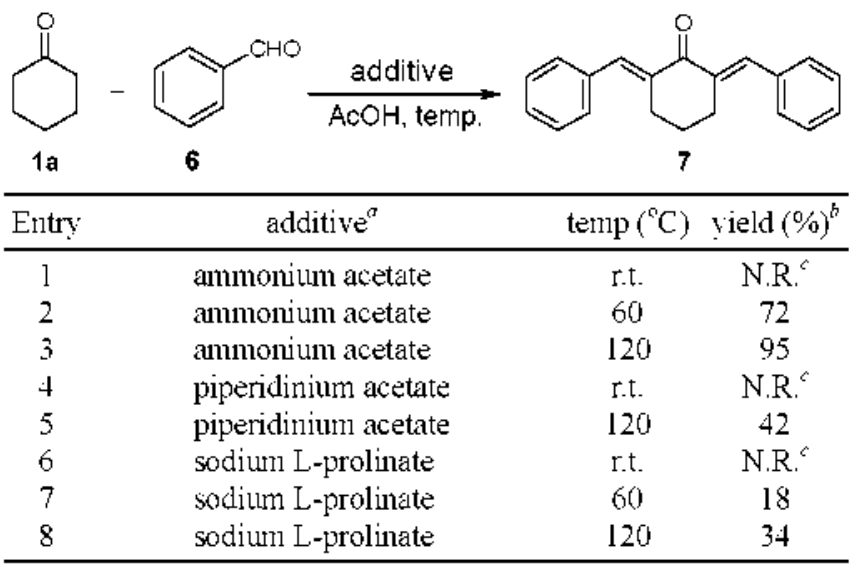

"Reaction was run in the presence of $10 \mathrm{~mol}^{0} \mathrm{i}$ additive relative to benzaldehyde and quenched after $8 \mathrm{~h}$. Isolated yields which are not optimized. "No product was detectable after 5 days.

niun acetate in glacial acetic acid, and results are summarized in Table 3. Reactions of cyclohexanone (1a) with 2 equiv of isopropyl aldehyde. acetaldehyde. and cyclohexanecarbaldelyde afforded the corresponding 2.6-bis(alkylidene)cyclohexanones. 3ab, 3ac, and 3af. in 78, 35, and $65 \%$ yield. respectively. It should be noted that the reaction of 1 a with acetaldehyde yielded a mixture of bis- (3ac) and monocondensed (4ac) product in $26 \%$ and $36 \%$ y ield respectively. The stereochemistry of the products was assigned as $E$ based on the literature values of olefinic $\mathrm{H}$ 's which were resonanced in the range of $\delta 6.62-6.92$ for $(E)$-isoner and $\delta 5.46-5.60$ for $(Z)$-isomer. ${ }^{\text {t2 }}$ Reactions of the other aliphatic aldehydes did not lead to any isolable desired products as reported. ${ }^{21 \mathrm{l}}$ but yielded $12-18 \%$ of 2 -alkylidene-alkanal as a self-condensed product and $25-35 \%$ of as yet unidentified mixtures of products. On the other hand, reactions of cyclopentanone (1b) afforded desired 2.5-bis(alkylidene)cyclopentanones in 35 $83 \%$ yield. The difference of reactivity of cyclohexanone $v$ cyclopentanone may be due to the difference of ring flexibility.

It should be noted that the reactions of aldehydes with a 
Table 3. The Claisen-Schnidt reaction of cycloalkanone 1 with aliphatic aldehydes 2

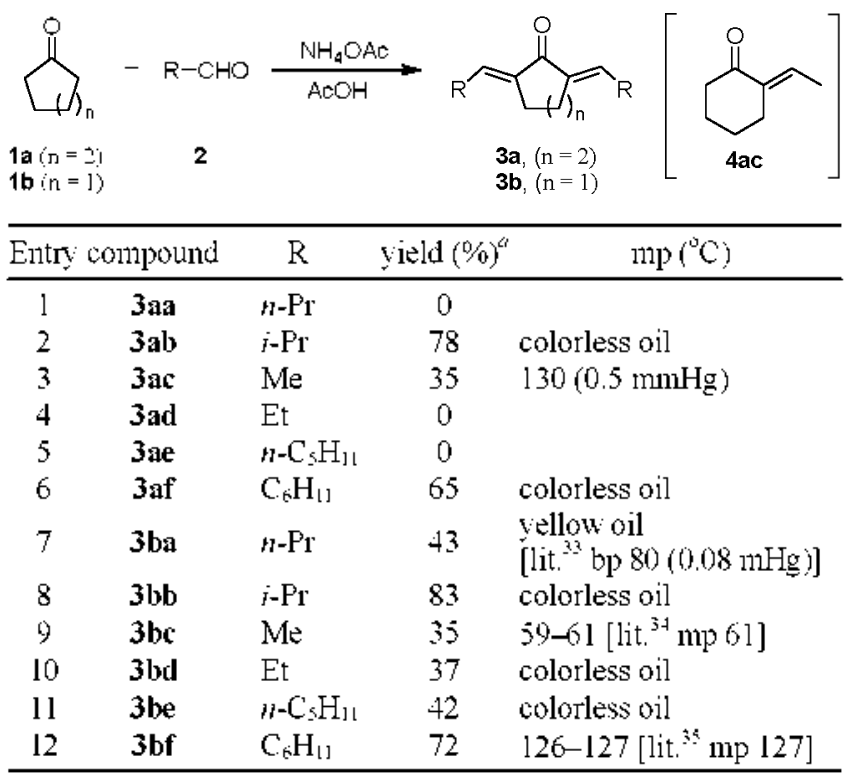

${ }^{a}$ Isolated yields which are not optimized.

Table 4. Reactions of mackinzaolinone (10) with benzaldehyde (6) in the presence of various additives in glacial acetic acid

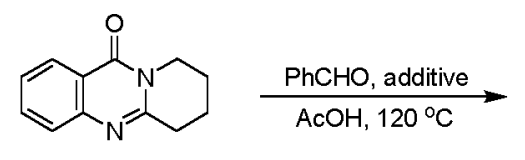

10

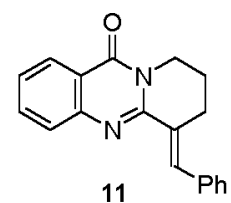

11

\begin{tabular}{clcc}
\hline Entry & \multicolumn{1}{c}{ additive $^{a}$} & time (h) & yield (\%) \\
\hline 1 & ammonium acetate & 4 & 86 \\
2 & ammonimin acetate & 8 & 95 \\
3 & piperidinium acetate & 4 & $<10$ \\
4 & piperidinium acetate & 120 & 90 \\
5 & triethylammonium acetate & 4 & $<10$ \\
6 & triethylammonium acetate & 72 & 86 \\
7 & sodium propanoate & 8 & 46 \\
8 & sodium propanoate & 36 & 86 \\
9 & acetamide & 4 & 86 \\
10 & acetamide & 72 & 90 \\
11 & sodium L-prolinate & 4 & 12 \\
12 & sodium L-prolinate & 8 & 40 \\
13 & acetic andydride & 4 & 18 \\
14 & acetic anliydride & 72 & 95 \\
\hline
\end{tabular}

${ }^{a}$ Reaction was run in the presence of $10 \mathrm{~mol}^{0} \mathrm{~b}$ additive relative to benzaldehyde. Isolated yields which are not optimized.

substituent at $\alpha$-position proceeded smoothly to yield the corresponding 2. $\omega$-bis(alkylidendene)derivatives in $65-83 \%$ yields (entries 2.6.8. and 12). Although a direct synthesis of 2.(1)-bis(alkylidene)cycloalkanones from cycloalkanones and alkyl aldehydes are known impractical ${ }^{\text {la:3:-26 }}$ the present method can be applicable for the direct preparation of 2,5 bis(alkylidene)cyclopentanones. especially from aldehydes with a substituent at the $\alpha$-position.

Effects of acetates on benzylidene-heteroammatics. The
Table 5. Reaction mackinazolinone (10) with aliphatic aldehydes with $10 \mathrm{~mol} \%$ additives in acetic acid

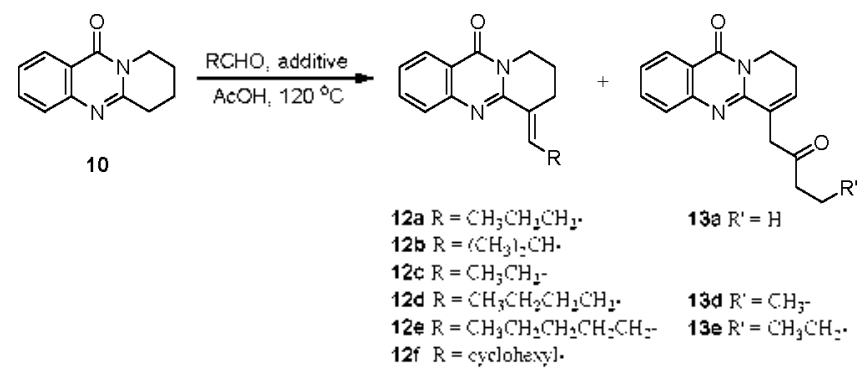

\begin{tabular}{clll}
\hline entry & \multicolumn{1}{c}{$\mathrm{R}$} & \multicolumn{1}{c}{ additive } & yield $(\%)^{n}(\mathbf{1 2 : 1 3})^{h}$ \\
\hline 1 & $n-\mathrm{Pr}$ & ammonium acetate & $71(25: 46)$ \\
2 & ${ }^{n}-\mathrm{Pr}$ & sodium acetate & $66(22: 44)$ \\
3 & $n-\mathrm{Pr}$ & sodium propanoate & $68(17: 51)$ \\
4 & $n-\mathrm{Pr}$ & acetamide & $63(14: 49)$ \\
5 & $i-\mathrm{Pr}$ & ammonium acetate & $70(12 \mathrm{~b}$ only $)$ \\
6 & $\mathrm{Et}$ & ammonium acetate & $67(12 \mathrm{c}$ only $)$ \\
7 & $n-\mathrm{Bu}$ & ammonium acetate & $91(83: 8)$ \\
8 & $n-\mathrm{C}_{5} \mathrm{H}_{31}$ & ammonium acetate & $70(23: 47)$ \\
9 & cyclohesyl & ammonium acetate & $96(12 \mathrm{f}$ only $)$ \\
\hline
\end{tabular}

"Isolated yields which are not optimized. "ratios of isolated products.

effect of acetates in glacial acetic acid on the reaction of 6.7.8.9-tetrahydro-11 $H$-py rido[2.1-b]quinazolin-1 1 -one (mackinazolinone. 10). was examined and results are summarized in Table 4 . Reaction at $120^{\circ} \mathrm{C}$ with ammonium acetate completed in $8 \mathrm{~h}$ while reactions with sodium propanoate, triethylammonium acetate. acetamide. and acetic anhydride required longer reaction time up to $120 \mathrm{~h}$. As described above, anmonium acetate can be a better cataly st for aldol-ty pe condensation reactions.

Effects of aliphatic aldehydes on alkylidene-hetervaromatics. Previous study revealed that the anylidene derivatives of selected heteroaromatics were effectively prepared by condensing with aromatic aldehyde in the presence of 10 $\mathrm{mol} \%$ of sodium acetate in glacial acetic acid. ${ }^{27}$ However. no systematic study on aliphatic aldelydes has been pursued as yet. We. thus. examined the reactivity of aldehydes towards mackinazolinone (10) and results are summarized in Table 5.

The reactions with propionaldehy'de, isobuty raldehy'de and cyclohexanecarbaldeliyde led the corresponding alkylidene derivatives (12b,c.f) in 67.96\% yields (entries 5.6 , and 9), which was superior to the $22-33 \%$ yields reported previously. ${ }^{1+4}$ However. the reactions with buty raldehyde, pentanal and hexanal yielded mixtures of two compounds $\mathbf{1 2}$ and $\mathbf{1 3}$. Reactions of butyraldehyde in presence of various acetates (entries 1-4) in glacial acetic acid afforded the corresponding alkylidene derivatives $12 \mathrm{a}$ in $14-25 \%$ yields along with an unexpected 13 a in $4+51 \%$ yields. Similarly. reactions with pentanal in the presence of ammonium acetate (entry 7) afforded 12d and 13d in $83 \%$ and $8 \%$ yields. respectively, while hexanal yielded $12 \mathrm{e}$ and $13 \mathrm{e}$ in $23 \%$ and $47 \%$ yield. respectively. It should be noted that attentpts (data not shown) to react 10 with aliphatic aldelyy des under the refluxing acetic anlydride for $72 \mathrm{~h}$ provided the products in only $<8 \%$ yield. which is not consistent with results described above for the 
reactions with aromatic aldehydes (Table 4. entry 14).

The structures of 13 were determined by spectroscopic methods including various NMR techniques such as HMBC and DEPT-135. Reaction mechanism for the formation of $\mathbf{1 3}$ remained to be clarified.

\section{Conclusion}

Effects of acetates as well as other factors on the aldol-type condensation reactions of cycloalkanones and mackinazolinone with various aldelydes were examined. Catalytic amount ( $10 \mathrm{~mol} \%$ relative to aldehy'de) of ammonium acetate in glacial acetic acid was good enough to lead best results at $120^{\circ} \mathrm{C}$. Reactions of cyclopentanone with aliphatic aldehy'des led the corresponding 2.5-bis(alkylidene)cyclopentanones in $35-83 \%$ yield while reactions of cyclohexanone were proceeded only with acetaldehyde. isobuty raldehyde and cyclohexanecarbaldehyde. Best results in the introduction of alkylidene moiety at the peri-position of carbocycle-fused heterocycles were achieved when ammonium acetate was employed as a catalyst.

\section{Experimental}

Melting points were recorded on a Fisher-Jones melting point apparatus and are uncorrected. Infrared spectra (IR) were recorded using $\mathrm{KBr}$ pellets for solids and neat for liquids on FT/IR-300 E (Jasco) spectrometer. Nuclear magnetic resonance (NMR) spectra were performed using Bruker 250 spectrometer $\left(250 \mathrm{MHz}\right.$ for ${ }^{1} \mathrm{H}$ NMR and $62.5 \mathrm{MHz}$ for ${ }^{13} \mathrm{C}$ $\mathrm{NMR}$ ) or Bnker 400 spectrometer $\left(400 \mathrm{MHz}\right.$ for ${ }^{\mathrm{l}} \mathrm{H} \mathrm{NMR}$ and $100 \mathrm{MHz}$ for ${ }^{13} \mathrm{C}$ NMR) and are reported as a parts per million (ppm) from the internal standard tetramethylsilane (TMS). Cyclohexanone was redistilled just before the reactions. Electrospray ionization (ESI) mass spectrometry (MS) experiments were performed on LCQ advantage-trap mass spectrometer (Thermo Finuigan. San Jose. CA. USA). Elemental analy'ses were taken on Hewlett-Packard Model 185B elemental analyzer.

General procedure for the preparation of $3,7,11$ and 12 . A mixture of cyclohexanone $(5.0 \mathrm{mmol})$. aldehyde $(10.0 \mathrm{mmol})$ and anhydrous acetate or related salts $(1.0 \mathrm{mmol})$ in glacial acetic acid ( $15 \mathrm{~mL}$ ) was heated under the conditions described in Table 1, 2. and 3. The reaction mixture was poured into crashed ice, and work up as usual afforded an oily material. which was chromatographed on silica gel eluting with $\mathrm{CH}_{2} \mathrm{Cl}_{2}$ :hexanes (1:1) to give analy tically pure $\alpha \cdot \alpha^{\prime}$-bis(alkylidene)cycloalkanones 3 and 2.6-bis(benzy lidene)cyclohexanones 7 except for 7 a described specifically. The spectral and analytical data of the $t h k n o w n$ compounds are given below.

2,6-Bis(ethylidene)cyclohexanone (3ac): A mixture of cyclohexanone $(0.52 \mathrm{~g}, 5.0 \mathrm{mmol})$. acetaldehyde $(0.66 \mathrm{~g} .15 .0$ $\mathrm{mmol}$ ) and anhydrous ammonium acetate $(77 \mathrm{mg} .1 .0 \mathrm{mmol}$. $10 \%$ equiv) in glacial acetic acid $\left(5 \mathrm{~mL}\right.$ ) was heated at $60{ }^{\circ} \mathrm{C}$ for $8 \mathrm{~h}$ under $\mathrm{N}_{2}$ atmosphere in a sealed tube. The reaction mixture was poured to crashed ice and extracted with $\mathrm{Et}_{2} \mathrm{O}$ (30 $\mathrm{mL} \times 3$ ). Combined organic layers were washed with water. brine and dried over $\mathrm{MgSO}_{4}$. Evaporation of the solvent afforded an oily material which was distilled under reduced pressure.

The early fractions afforded $(\boldsymbol{E})$-2-ethylidenecyclohexanone (4ac) as colorless oil (0.16 g. $26 \%$ yield) bp $76-80^{\circ} \mathrm{C}$ $(1+\mathrm{nmHg})$ [lit. ${ }^{36}$ bp $87-89^{\circ} \mathrm{C}(18 \mathrm{mmHg})$ ]; IR (KBr) v 1670 , $1612 \mathrm{~cm}^{-1}:{ }^{1} \mathrm{H} \mathrm{NMR}\left(\mathrm{CDCl}_{3} .250 \mathrm{MHz}\right) \delta$ oे 6.68 (1H. qt. $J=7.5$. $2.0 \mathrm{~Hz}), 2.41(2 \mathrm{H} . \mathrm{t}, J=5.9 \mathrm{~Hz}) .2 .37(2 \mathrm{H} . \mathrm{t} . J=6.5 \mathrm{~Hz}), 1.72$ $(3 \mathrm{H}, \mathrm{d}, J=7.5 \mathrm{~Hz}), 1.12-1.11(4 \mathrm{H}, \mathrm{m}):{ }^{13} \mathrm{C} \mathrm{NMR}\left(\mathrm{CDCl}_{2}, 62.5\right.$ $\mathrm{MHz}$ ) ô 200.87. 137.03, 134.17, 39.96, 26.23. 23.36. 23.21, 13.40

The latter fractions afforded 2,6-bis(ethylidene)cyclohexanone (3ac) as colorless oil $\left(0.26 \mathrm{~g} .35 \%\right.$ yield): bp $130^{\circ} \mathrm{C}$ $(0.5 \mathrm{mmHg})$ : IR (KBr) v $1668,1615 \mathrm{~cm}^{-1}$ : ${ }^{1} \mathrm{H}$ NMR $\left(\mathrm{CDCl}_{3}\right.$. $250 \mathrm{MHz}) \delta 6.85(2 \mathrm{H}, \mathrm{qm}, J=7.5 \mathrm{~Hz}), 2.45(4 \mathrm{H}, \mathrm{t} . J=5.9 \mathrm{H})$, $1.72(6 \mathrm{H} . \mathrm{d} J=7.5 \mathrm{~Hz}) .1 .12-1.11(2 \mathrm{H}, \mathrm{m}) .{ }^{13} \mathrm{C} \mathrm{NMR}\left(\mathrm{CDCl}_{3}\right.$. $62.5 \mathrm{MHz}) \delta 188.99 .136 .67 .135 .15 .25 .89,21.98,13.78: \mathrm{MS}$ (ESI) calcd for $\mathrm{C}_{10} \mathrm{H}_{15} \mathrm{O}[\mathrm{M}+\mathrm{H}]^{-}: 151$, found 151

2,6-Bis(cyclohexylmethylidene)cyclohexanone (3a): Colorless oil. ${ }^{1} \mathrm{H}$ NMR $\left(\mathrm{CDCl}_{3} .250 \mathrm{MHz}\right) \delta 6.52(2 \mathrm{H} . \mathrm{d}, J=9.7$ Hz). 2.5 l-2.45 (4H. m). 2.13-2.05 (2H. m). 1.85-1.55 (14H. m). 1.24-1.09 (8H. m): ${ }^{13} \mathrm{C}$ NMR $\left(\mathrm{CDCl}_{3}, 62.5 \mathrm{MHz}\right) \hat{o}$ 185.57. 14t.25. 134.41, 40.20, 36.71. 31.73. 26.64. 23.72, 23. 35: MS (ESI) calcd for $\mathrm{C}_{31} \mathrm{H}_{31} \mathrm{O}\left[\mathrm{M}+\mathrm{H}^{+}: 287\right.$, found: 287 .

2,5-Bis(butylidene)cyclopentanone (3ba): Colorless oil. IR (KBr) v $1621 \mathrm{~cm}^{-1}:{ }^{1} \mathrm{H}$ NMR $\left(\mathrm{CDCl}_{3,} 250 \mathrm{MHz}\right)$ oे 6.52 (2H. d. $J=9.7 \mathrm{~Hz}) .2 .51-2.45(4 \mathrm{H}, \mathrm{m}) .2 .13-2.05(2 \mathrm{H}, \mathrm{m}), 1.85-1.55$ $(\mathrm{l} 4 \mathrm{H}, \mathrm{m}), 1.24-1.09(8 \mathrm{H}, \mathrm{m}):{ }^{13} \mathrm{C} \mathrm{NMR}\left(\mathrm{CDCl}_{3}, 62.5 \mathrm{MHz}\right) \hat{\delta}$ $185.57,144.25,134.41,40.20,36.71,31.73,26.64,23.72$, 23.35: MS (ESI) calcd for $\mathrm{C}_{13} \mathrm{H}_{21} \mathrm{O}[\mathrm{M}+\mathrm{H}]^{+}:$: 193 . found: 193

2,5-Bis(propylidene)cyclopentanone (3bd): Colorless oil. IR (KBr) v $1621 \mathrm{~cm}^{-1}$ : ${ }^{*} \mathrm{H}$ NMR $\left(\mathrm{CDCl}_{3}, 250 \mathrm{MHz}\right)$ ô 6.52 $(2 \mathrm{H}$. d. $J=9.7 \mathrm{~Hz}) .2 .5 \mathrm{l}-2.45(4 \mathrm{H}, \mathrm{m}), 2.13-2.05(2 \mathrm{H} . \mathrm{m})$. 1.85-1.55 (1+ H. m). 1.24-1.09 (8H, m): ${ }^{13} \mathrm{C} \mathrm{NMR} \mathrm{(CDCl}$, $62.5 \mathrm{MHz}) \delta 185.57,144.25 .134 .41,40.20 .36 .71 .31 .73$, $26.64,23.72,23.35$ : MS (ESI) calcd for $\mathrm{C}_{11} \mathrm{H}_{17} \mathrm{O}[\mathrm{M}+\mathrm{H}]^{+}$: 165 . found 165

2,5-Bis(hexylidene)cyclopentanone (3be): Colorless oil. IR (KBr) v $1621 \mathrm{~cm}^{-1}$ : ${ }^{1} \mathrm{H}$ NMR $\left(\mathrm{CDCl}_{3}, 250 \mathrm{MHz}\right)$ ô 6.52 $(2 \mathrm{H}$. d. $J=9.7 \mathrm{~Hz}) .2 .5 \mathrm{l}-2.45(4 \mathrm{H}, \mathrm{m}), 2.13-2.05(2 \mathrm{H}, \mathrm{m})$, $1.85-1.55(\mathrm{l}+\mathrm{H}, \mathrm{m}) .1 .24-1.09(8 \mathrm{H}, \mathrm{m}):{ }^{13} \mathrm{C} \mathrm{NMR}\left(\mathrm{CDCl}_{3}\right.$, $62.5 \mathrm{MHz}) \delta 185.57,144.25 .134 .41,40.20 .36 .71 .31 .73$, $26.64,23.72,23.35$ : MS (ESI) calcd for $\mathrm{C}_{17} \mathrm{H}_{2} \mathrm{O}[\mathrm{M}+\mathrm{H}]^{+}$: 249. found: 249 .

General procedure for the preparation of 6-alkylidene6,7,8,9-tetrahydro-11 $H$-py rido[2,1-b]quinazolin-11-ones 12.

(E)-6-Butylidene-6,7,8,9-tetrahydro- $11 H$-pyyido $[2,1-b]$ quinazolin-11-one (12a): A mixture of 6.7.8.9-tetrahy'dro- $11 \mathrm{H}$ py rido[2,1-b]quina-zolin-11-one (10) (1.0 g. $5.0 \mathrm{mmol})$. $n$ butanal $(0.72 \mathrm{~g} .5 .0 \mathrm{~mol})$, and acetates or related compounds ( $0.5 \mathrm{~nm}$ ol, $10 \%$ molar equiv) in $10 \mathrm{~nL}$ of glacial acetic acid was heated at $120^{\circ} \mathrm{C}$. The resulting mixture was poured to $10 \% \mathrm{NaOH}(40 \mathrm{~mL})$ and extracted with $\mathrm{CH}_{2} \mathrm{Cl}_{2}(30 \mathrm{~mL} \times 3)$. The combined organic layers were dried over $\mathrm{MgSO}_{4}$. Evaporation of the solvent gave a greenish yellow solid which was purified by silica gel colunu chromatography eluting with hexanes:EtOAc $(1: 1)$.

The early fractions $\left(R_{\mathrm{f}} 0.75\right)$ afforded the desired product $12 \mathrm{a}$ as an $(E)$-isomer as yellow needles $(0.32 \mathrm{~g} .25 \%$ yield): mp 87-88 ${ }^{\circ} \mathrm{C}:{ }^{\mathrm{l}} \mathrm{H} \mathrm{NMR}\left(\mathrm{CDCl}_{3 .} 400 \mathrm{MHz}\right) \hat{\delta} 8.22$ (1H. d. $J=$ 
$7.6 \mathrm{~Hz}) .7 .70-7.61(2 \mathrm{H}, \mathrm{m}) .7 .36(\mathrm{lH}$. ddd $J=7.9 .6 .5 .1 .8$ Hz). 7.19 ( $1 \mathrm{H}$. ddd. $J=8.0 .7 .5 .1 .2 \mathrm{~Hz})+4.02(2 \mathrm{H} . \mathrm{t} . J=5.7$ Hz). $2.58(2 \mathrm{H}, \mathrm{t}, J=5.3 \mathrm{~Hz}) .2 .18(2 \mathrm{H}$. dt. $J=7.4 .6 .3 \mathrm{~Hz})$. $1.96(2 \mathrm{H}$, quintet. $J=6.3 \mathrm{~Hz}) .1 .56(2 \mathrm{H}, \mathrm{q}, J=7.5 \mathrm{~Hz}) .0 .97$ (3H. t. $J=7.5 \mathrm{~Hz}),{ }^{13} \mathrm{C} \mathrm{NMR}\left(\mathrm{CDCl}_{\hat{j}} .62 .5 \mathrm{MHz}\right) \delta 162.12$. 151.70. 147.64, 139.12, 133.99. 128.82, 127.12, 126.56. $125.82,119.95,42.07,30.83,24.37,24.03,22.74,21.93$. 21.74, 14.10: $\mathrm{MS}$ (ESI) calcd for $\mathrm{C}_{16} \mathrm{H}_{13} \mathrm{~N}_{2} \mathrm{O}[\mathrm{M}+\mathrm{H}]^{-}: 255$. found: 255 . Anal. Calcd for $\mathrm{C}_{16} \mathrm{H}_{1 \S} \mathrm{N}_{2} \mathrm{O}: \mathrm{C}, 75.56 ; \mathrm{H} .7 .13 ; \mathrm{N}$. 11.01. Found: C. 75.72: H. 7.06: N. 11.08.

The latter fractions $\left(R_{\mathrm{f}} 0.40\right)$ afforded the compound $13 \mathrm{a}$ (0.67 g. $46 \%$ yield): mp $107-108{ }^{\circ} \mathrm{C}:{ }^{1} \mathrm{H}$ NMR (CDCl $\mathrm{S}_{3} 400$ $\mathrm{MHz}) \hat{\delta} 8.23$ (1H. dd. $J=8.0,1.2 \mathrm{~Hz}) .7 .65(1 \mathrm{H}, \mathrm{td}, J=8.0,0.8$ Hz). $7.53(\mathrm{lH} . \mathrm{d} . J=8.0 \mathrm{~Hz}) .7 .40(\mathrm{lH} . \mathrm{td} . J=8.0 .1 .0 \mathrm{~Hz}$ ). $6.5 \mathrm{l}(\mathrm{lH} . \mathrm{t} . J=4.5 \mathrm{~Hz}) .4 .26(2 \mathrm{H}, \mathrm{t} . J=7.0 \mathrm{~Hz}) .3 .61(2 \mathrm{H} . \mathrm{s})$. $2.68(2 \mathrm{H} . \mathrm{q}, J=7.3 \mathrm{~Hz}), 2.58(2 \mathrm{H} . \mathrm{td} . J=7.0 .6 .8 \mathrm{~Hz}) .1 .10$ (3H. t. $J=7.5 \mathrm{~Hz}):{ }^{13} \mathrm{C} \mathrm{NMR}\left(\mathrm{CDCl}_{3} .62 .5 \mathrm{MHz}\right) \dot{o} 208.9$ $\left(\mathrm{C}_{2}=\mathrm{O}\right) .161 .+\left(\mathrm{C}_{11}=\mathrm{O}\right), 1+8.8\left(\mathrm{C}_{53}\right), 1+7.2\left(\mathrm{C}_{4 a}\right), 136.6\left(\mathrm{C}_{7}\right)$. $133.9\left(\mathrm{C}_{3}\right), 130.2\left(\mathrm{C}_{6}\right), 127.4\left(\mathrm{C}_{4}\right), 126.89\left(\mathrm{C}_{1}\right), 126.60\left(\mathrm{C}_{3}\right)$. $121.1\left(\mathrm{C}_{1(\mathrm{1})}\right) .44 .8\left(\mathrm{C}_{1}\right), 38.6\left(\mathrm{C}_{9}\right) .36 .2\left(\mathrm{C}_{3}\right), 23.0\left(\mathrm{C}_{8}\right) .7 .93$ $\left(\mathrm{C}_{4}\right)$ : $\mathrm{MS}(\mathrm{ESI})$ calcd for $\mathrm{C}_{16} \mathrm{H}_{17} \mathrm{~N}_{2} \mathrm{O}_{2}[\mathrm{M}+\mathrm{H}]^{-}: 269$. found: 269. Anal. Calcd for $\mathrm{C}_{16} \mathrm{H}_{16} \mathrm{~N}_{2} \mathrm{O}_{2}:$ : C. 71.62: H. 6.01: N. 10.44 . Found: C, $71.85 ;$ H. $5.97 ;$ N, 10.61 .

(E)-6-Isobutylidene-6,7,8,9-tetrahydro-11 $H$-pynido $[2,1-b]-$ quinazolin-11-one (12b): Pale yellow needles $\left[R_{\mathrm{l}} 0.80\right.$ hexanes:EtOAc ( $1: 1)$ ] (70\% yield): $\mathrm{mp} 103{ }^{\circ} \mathrm{C}:{ }^{1} \mathrm{H}$ NMR $\left(\mathrm{CDCl}_{3}\right.$. $250 \mathrm{MHz}) \hat{o} 8.22(1 \mathrm{H}, \mathrm{d}, J=7.8 \mathrm{~Hz}) .7 .71-7.61(2 \mathrm{H}, \mathrm{m}) .8 .36$ (1H. ddd. $J=8.0,7.5,1.0 \mathrm{~Hz}), 7.07(1 \mathrm{H} . \mathrm{dt}, J=10.0 .1 .5 \mathrm{~Hz}$, vinylic $\mathrm{H}$ ) $4.09(2 \mathrm{H}$ dd $J=6.8 .5 .8 \mathrm{~Hz}), 2.72$ (lH. heptet. $J$ $=6.8 \mathrm{~Hz}), 2.63(2 \mathrm{H}, \mathrm{td}, J=5.8 \mathrm{~Hz}) .1 .97(2 \mathrm{H}$. quint, $J=5.8$ $\mathrm{Hz}) .1 .10(6 \mathrm{H}, \mathrm{d}, J=6.8 \mathrm{~Hz}):{ }^{13} \mathrm{C} \mathrm{NMR}\left(\mathrm{CDCl}_{3}, 62.5 \mathrm{MHz}\right) \delta$ $162.15 .151 .68,147.52,145.56,133.93,127.07,126.64$. 126.47. 125.78, 119.84, 42.18, 27.86. 23.72. 22.02, 21.71: MS (ESI) calcd for $\mathrm{C}_{16} \mathrm{H}_{18} \mathrm{~N}_{2} \mathrm{O}: 255[\mathrm{M}+\mathrm{H}]^{+}$. found: 255 . Anal. Calcd for $\mathrm{C}_{16} \mathrm{H}_{18} \mathrm{~N}_{2} \mathrm{O}: \mathrm{C}, 75.56 ; \mathrm{H} .7 .13 ; \mathrm{N}, 11.01$. Found: C. 75.62: H. 7.12: N. 11.04

(E)-6-Propylidene-6,7,8,9-tetrahydro-11 $H$-py rido[2,1-b]quinazolin-11-one (12c): Pale yellow needles $\left[R_{\mathrm{f}} 0.80\right.$ hexanes: EtOAc (1:1)] (67\%): mp 125-126 ${ }^{\circ} \mathrm{C}:{ }^{\mathrm{l}} \mathrm{H}$ NMR (CDCl 2.250 $\mathrm{MHz}) \delta 8.23(1 \mathrm{H}, \mathrm{dd}, J=7.8,0.8 \mathrm{~Hz}) .7 .65(2 \mathrm{H}, \mathrm{m}), 7.38(1 \mathrm{H}$, td. $J=8.0 .0 .8 \mathrm{~Hz}) .7 .19(\mathrm{lH} . \mathrm{td} . J=8.0 .1 .0 \mathrm{~Hz}) .4 .11(2 \mathrm{H} . \mathrm{t}$. $J=5.6 \mathrm{~Hz}), 2.61(2 \mathrm{H}, \mathrm{t}, J=5.6 \mathrm{~Hz}), 2.26(2 \mathrm{H}$. quintet, $J=7.5$ $\mathrm{Hz}) .2 .02-1.89(2 \mathrm{H}, \mathrm{m}), 1.16(3 \mathrm{H}, \mathrm{t} . J=7.5 \mathrm{~Hz}):{ }^{13} \mathrm{C} \mathrm{NMR}$ $\left(\mathrm{CDCl}_{3}, 62.5 \mathrm{MHz}\right)$ ò $162.13,151.75,147.63,140.72 .134 .04$. 128.29. 127.11. 126.70. 126.59. 126.01. 125.87. 119.95. $42.05,23.90 .22 .07 .21 .72,13.16: \mathrm{MS}$ (ESI) calcd for $\mathrm{C}_{1 \leqslant} \mathrm{H}_{17-}$ $\mathrm{N}_{2} \mathrm{O}[\mathrm{M}+\mathrm{H}]^{-}: 2+1$. found: 241 . Anal. Calcd for $\mathrm{C}_{15} \mathrm{H}_{16} \mathrm{~N}_{2} \mathrm{O}: \mathrm{C}$, 74.97: H. 6.71: N. 11.66. Found: C. 75.03: H. 6.68: N. 11.64.

(E)-4-Pentylidene-1,2,3,4-tetrahydro-11H-pyrido [2,1-b]quinazolin-11-one (12d): Pale yellow needles $\left[\begin{array}{ll}R_{\mathrm{f}} & 0.5\end{array}\right]$ hexanes: EtOAc (2:1)] ( $83 \%$ yield): mp 86-87 ${ }^{\circ} \mathrm{C}:{ }^{1} \mathrm{H}$ NMR $\left(\mathrm{CDCl}_{3} .250 \mathrm{MHz}\right) \delta 8.21(1 \mathrm{H} . \mathrm{dd}, J=7.8 .0 .4 \mathrm{~Hz}) .7 .70-7.61$ $(2 \mathrm{H}, \mathrm{m}) .7 .36(\mathrm{lH}$, ddd $J=8.0,7.8 .0 .8 \mathrm{~Hz}) .7 .19(1 \mathrm{H}, \mathrm{ddd} . J$ $=8.0,7.8,1.0 \mathrm{~Hz}) .4 .08(2 \mathrm{H}$. dd. $J=11.4 .5 .7 \mathrm{~Hz}), 2.60(2 \mathrm{H}$, t. $J=6.3 \mathrm{~Hz}) .2 .27(2 \mathrm{H}, \mathrm{q} . J=7.5 \mathrm{~Hz}), 1.96(2 \mathrm{H}$. quintet. $J=$ $7.5 \mathrm{~Hz}), 1.50(2 \mathrm{H}$, quintet, $J=7.5 \mathrm{~Hz}) .1 .38(2 \mathrm{H}$, quintet, $J=$ $7.5 \mathrm{~Hz}) .0 .91(3 \mathrm{H}, \mathrm{t}, J=7.5 \mathrm{~Hz}) ;{ }^{13} \mathrm{C} \mathrm{NMR}\left(\mathrm{CDCl}_{3}, 62.5 \mathrm{MHz}\right)$ ò $162.12,151.75,147.60 .140 .40 .139 .40,134.00,128.59$.
$127.06 .126 .54,125.81,119.89 .42 .06 .30 .75 .28 .49,23.96$, 22.58.21.71. 13.92: MS (ESI) calcd for $\mathrm{C}_{17} \mathrm{H}_{21} \mathrm{~N}_{2} \mathrm{O}[\mathrm{M}+\mathrm{H}]^{+}$ 269. found: 269. Anal. Calcd for $\mathrm{C}_{17} \mathrm{H}_{2} \mathrm{~N}_{2} \mathrm{O}:$ C. $76.09: \mathrm{H}$, 7.51: N, 10.44. Found: C, 76.06; H. 7.52; N. 10.46.

The latter fractions $\left[R_{i} 0.32\right.$ hexanes:EtOAc $\left.(2: 1)\right]$ afforded $13 d$ as a pale yellow oil ( $8 \%$ yield). ${ }^{\mathrm{H}} \mathrm{H} \mathrm{NMR}\left(\mathrm{CDCl}_{3} .250\right.$ $\mathrm{MHz}) \hat{o} 8.22(\mathrm{iH}, \mathrm{d}, J=8.0 \mathrm{~Hz}) .7 .64(\mathrm{lH}, \mathrm{td} J=8.0 .0 .8 \mathrm{~Hz}$ ). $7.52(1 \mathrm{H}, \mathrm{d}, J=8.0 \mathrm{~Hz}), 7.38(1 \mathrm{H} . \mathrm{td} . J=8.0,1.0 \mathrm{~Hz}) .6 .50$ $(1 \mathrm{H} . \mathrm{t} . J=4.8 \mathrm{~Hz}), 4.27(2 \mathrm{H} . \mathrm{t}, J=7.0 \mathrm{~Hz}), 3.61(2 \mathrm{H}, \mathrm{s}), 2.63$ $(2 \mathrm{H}, \mathrm{q} . J=7.3 \mathrm{~Hz}) .2 .55(2 \mathrm{H}, \mathrm{td}, J=7.0,6.8 \mathrm{~Hz}) .1 .6 \mathrm{l}(2 \mathrm{H}$. quintet. $J=7.5 \mathrm{~Hz}), 0.91(3 \mathrm{H}, \mathrm{t} . J=7.5 \mathrm{~Hz}),{ }^{12} \mathrm{C} \mathrm{NMR}\left(\mathrm{CDCl}_{3}\right.$, $62.5 \mathrm{MHz}) \delta 208.0\left(\mathrm{C}_{2}=\mathrm{O}\right) .161 .0\left(\mathrm{C}_{11}=\mathrm{O}\right) .148 .7\left(\mathrm{C}_{54}\right) .147 .2$ $\left(\mathrm{C}_{4 \mathrm{a}}\right) .136 .6\left(\mathrm{C}_{7}\right) .133 .9\left(\mathrm{C}_{3}\right) .130 .2\left(\mathrm{C}_{6}\right) \cdot 127.4\left(\mathrm{C}_{4}\right) .126 .77$ $\left(\mathrm{C}_{1}\right) .126 .56\left(\mathrm{C}_{2}\right), 121.1\left(\mathrm{C}_{1, k}\right) .44 .8\left(\mathrm{C}_{1}\right), 42.6\left(\mathrm{C}_{0}\right), 38.0$ $\left(\mathrm{C}_{3}\right), 25.7\left(\mathrm{C}_{8}\right), 23.0\left(\mathrm{C}_{4}\right) .14 .9\left(\mathrm{C}_{5}\right)$ : MS (ESI) calcd for $\mathrm{C}_{17} \mathrm{H}_{19} \mathrm{~N}_{2} \mathrm{O}_{2}[\mathrm{M}+\mathrm{H}]^{-}:$283. found: 283. Anal. Calcd for $\mathrm{C}_{17} \mathrm{H}_{18} \mathrm{~N}_{2} \mathrm{O}_{2}:$ C. $72.95: \mathrm{H}, 6.80: \mathrm{N}, 9.45$. Found: C. $72.89: \mathrm{H}$, 6.82: N, 9.51

(E)-6-Hexylidene-6,7,8,9-tetıahydm-11 $H$-pylido[2,1-b]quinazolin-11-one (12e): Semisolid $\left[R_{\mathrm{i}} 0.42\right.$ hexanes: $\mathrm{EtOAC}$ $(2: 1)]$ (23\% yield). ${ }^{1} \mathrm{H}$ NMR $\left(\mathrm{CDCl}_{3} .250 \mathrm{MHz}\right) \delta 8.26(1 \mathrm{H}, \mathrm{d}$, $J=7.8 \mathrm{~Hz}) .7 .73-7.66(2 \mathrm{H}, \mathrm{m}) .7 .42(\mathrm{lH}, \mathrm{td}, J=8.0,0.8 \mathrm{~Hz})$. $7.18(1 \mathrm{H}, \mathrm{t}, J=8.0 \mathrm{~Hz}), 4.13(2 \mathrm{H}, \mathrm{dd}, J=11.0,5.8 \mathrm{~Hz}) .2 .74$ $(2 \mathrm{H}, \mathrm{m}), 2.12-1.83(4 \mathrm{H}, \mathrm{m}), 1.22-1.13(6 \mathrm{H}, \mathrm{m}), 0.84(3 \mathrm{H}, \mathrm{t}, J$

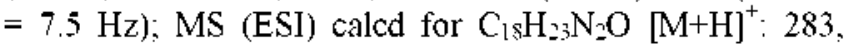
found: 283 . Anal. Cald for $\mathrm{C}_{18} \mathrm{H}_{22} \mathrm{~N}_{2} \mathrm{O}: \mathrm{C}, 76.56: \mathrm{H}, 7.85: \mathrm{N}$. 9.92. Found: C. 86.55: H, 7.84: N, 9.94.

The latter fractions $\left[R_{f} 0.28\right.$ hexanes:EtOAc $\left.(2: 1)\right]$ afforded $13 \mathrm{e}$ as a pale yellow needles $\left(47 \%\right.$ yield): $\mathrm{mp} 98-99{ }^{\circ} \mathrm{C}:{ }^{\prime} \mathrm{H}$ $\mathrm{NMR}\left(\mathrm{CDCl}_{3} .250 \mathrm{MHz}\right) \hat{o} 8.2+(1 \mathrm{H} . \mathrm{d} . J=8.0 \mathrm{~Hz}), 7.65(\mathrm{lH}$, td. $J=8.0 .0 .8 \mathrm{~Hz}) .7 .52(1 \mathrm{H}, \mathrm{d} . J=8.0 \mathrm{~Hz}) .7 .40(\mathrm{lH} . \mathrm{td}, J=$ $8.0 .1 .0 \mathrm{~Hz}), 6.50(1 \mathrm{H} . \mathrm{t}, J=4.8 \mathrm{~Hz}), 4.27(2 \mathrm{H} . \mathrm{t}, J=7.0 \mathrm{~Hz})$, $3.61(2 \mathrm{H} . \mathrm{s}) .2 .64(2 \mathrm{H}, \mathrm{q}, J=7.3 \mathrm{~Hz}), 2.56(2 \mathrm{H} . \mathrm{td}, J=7.0 .6 .8$ $\mathrm{Hz}) .1 .6 \mathrm{l}(2 \mathrm{H}$, quintet. $J=7.5 \mathrm{~Hz}), 1.27(2 \mathrm{H}$. quintet. $J=7.5$ $\mathrm{Hz}) .0 .90(3 \mathrm{H}, \mathrm{t}, J=7.5 \mathrm{~Hz}):{ }^{13} \mathrm{CNMR}\left(\mathrm{CDCl}_{3}, 62.5 \mathrm{MHz}\right) \delta$ $208.5\left(\mathrm{C}_{2}=\mathrm{O}\right) .161 .4\left(\mathrm{C}_{11}=\mathrm{O}\right) .148 .8\left(\mathrm{C}_{5 \mathrm{a}}\right) .147 .2\left(\mathrm{C}_{44}\right) .136 .6$ (C) $.133 .9\left(\mathrm{C}_{3}\right) .130 .2\left(\mathrm{C}_{6}\right) .127 .4\left(\mathrm{C}_{4}\right) .126 .77\left(\mathrm{C}_{1}\right), 126.56$ $\left(\mathrm{C}_{2}\right) .121 .1\left(\mathrm{C}_{1} \mathrm{a}\right) .45 .1\left(\mathrm{C}_{1}\right) .+2.7\left(\mathrm{C}_{0}\right) .38 .6\left(\mathrm{C}_{3}\right) .25 .9\left(\mathrm{C}_{8}\right)$. $23.0\left(\mathrm{C}_{4}\right)^{\circ}, 22.3\left(\mathrm{C}_{5}\right) .13 .9\left(\mathrm{C}_{6}\right)$ : MS (ESI) calcd for $\mathrm{C}_{18} \mathrm{H}_{21}-$ $\mathrm{N}_{2} \mathrm{O}_{2}[\mathrm{M}+\mathrm{H}]^{+}: 297$. found: 297 . Anal. Calcd for $\mathrm{C}_{18} \mathrm{H}_{20} \mathrm{~N}_{2} \mathrm{O}_{2}$ : C. $72.95:$ H. $6.80:$ N. 9.45. Found: C. $72.92:$ H. 6.82: N. 9.48 .

(E)-6-Cyclohexylmethylidene-6,7,8,9-tetrahydro-11 $H$-pyrido[2,1- $b$ ]quinazolin-11-one (12f): Pale yellow needles (96\% yield): mp 169-170 ${ }^{\circ} \mathrm{C}$; ${ }^{l} \mathrm{H}$ NMR (CDCl, $\left.250 \mathrm{MHz}\right) \delta 8.22$ $(1 \mathrm{H} . \mathrm{d} . J=7.6 \mathrm{~Hz}), 7.71-7.6 \mathrm{l}(2 \mathrm{H}, \mathrm{m}) .7 .36(1 \mathrm{H} . \mathrm{ddd}, J=7.5$, $6.8 .1 .8 \mathrm{~Hz}) .7 .08(\mathrm{lH}, \mathrm{dt} . J=9.8,1.8 \mathrm{~Hz}), 4.10(2 \mathrm{H}, \mathrm{t} . J=5.8$ Hz). $2.65(2 \mathrm{H}, \mathrm{td} . J=7.9 .1 .7 \mathrm{~Hz}) .2 .38-2.34$ (1H. br. m). 1.97 (2H. quintet. $J=6.9 \mathrm{~Hz}), 1.76-1.69(5 \mathrm{H}, \mathrm{m}), 1.40-1.18(5 \mathrm{H}$, $\mathrm{m}) ;{ }^{13} \mathrm{C}$ NMR $\left(\mathrm{CDCl}_{3}, 62.5 \mathrm{MHz}\right)$ ô 162.25. 151.77. 147.62, $144.07,133.95,127.17,127.04,126.52,125.78,119.92$. 42.29, 37.87, 31.99, 25.89, 25.77, 23.88, 21.82: MS (ESI) calcd for $\mathrm{C}_{19} \mathrm{H}_{23} \mathrm{~N}_{2} \mathrm{O}[\mathrm{M}+\mathrm{H}]^{+}: 295$. found: 295 . Anal. Cald for $\mathrm{C}_{19} \mathrm{H}_{22} \mathrm{~N}_{2} \mathrm{O}: \mathrm{C} .77 .52: \mathrm{H}, 7.53: \mathrm{N}, 9.52$. Found: $\mathrm{C} .77 .55: \mathrm{H}$. $7.49: \mathrm{N}, 9.49$

Acknowledgments. Financial support from Korean Research Foundation (Grant No. KRF-2005-04l-E00496) is gratefully acknowledged. DHK is a recipient of BK-2 I scholarship. 


\section{References}

1. For reviews of aldol reaction, see: (a) Nielsen, A. T.; Houlihan, W. T. Organic Reactions: Adams, R.; Blatt, A. H.; Boekelheide, V.: Caims, T. L.; Cram, D. T.: House, H. O., Eds.; Joln Wiley \& Sons: New York, 1968; Vol. 16, p l. (b) Mukaiyama, T. Orgamic Reactions; Dauben, W. G., Ed.: Toln Wiley \& Sons: New York, 1982; Vol. 28, p 203. (c) Heathcock, C. H. In Conprehensive Organic Symthesis; Trost, B. M.: Fleming, I., Eds: Pergamon Press: Oxford, 1991; Vol. 2, p 133. (d) Gennari, C. In Contprehensive Organic Snnthesis: Trost, B. M.: Fleming, I., Eds.; Pergannon Press: Oxford, 1991; Vol. 2, p 629. (e) Malirwald, R. Hodem Aldol Reactions; Wiler-VCH-Verlag GmbH \& Co.: Gemany, 2004; Vol. 1 and 2. (f) Reeves, R. L. Chentstry of Carbonl Group: Patai, S., Ed.: Wiley Intersciences: New York, 1966: $p 580$

2. (a) Robinson, T. P; Ehlers, T.; Hubbard, R. B.; Bai, X ; Arbiser, I. L.: Goldsmith. D. J.; Bowena, J. P. Bioorg. hed. Chem. Lett. 2003, 13, 115 . (b) Robinson, T. P.; Hubbard, R. B.: Elllers, T. J.: Arbiser, J. L.; Goldsmith, D. J.; Bowen, I. P. Bioong. Med. Chem. $2005,13,4007$.

3. Dinkova-Kostova, A. T.; Abeygunawardana, C.; Talalav, P. $J$. Afed Chem. 1998, H, 5287 .

4. (a) Dimmock, I. R.; Padmanilayam, M. P.; Zello, G. A.; Nienaber, K. H.; Allen, T. M:; Santos, C. L.: De Clereq, E.; Balzarini, T. Manavathu, E. K.: Stables. T. P. Eur. J. Afed. Chem. 2003, 38, 169. (b) Modzelewska, A.: Pettit, C.; Achanta, G.: Davidson, N. E.; Huang, P.: Khan1, S. R. Bioorg. Med Chem. 2006, If, 3491.

5. Piantadosi, C.: Hall, I. H.; Irvine, I. L.: Carlson, G. L. J. Med. Chent $1973,16,770$.

6. Kawamata, J.; Inoue, K: Inabe, T:; Kiguchi, M: Kato, M.; Taniguchi, Y. Chem. Phos. Lett. 1996, 219, 29.

7. Deli, J.: Lorand, J.: Szabo, D.: Foldesi, A. Phamazie 1984, 39 , 539.

8. Leonard, N. T.; Miller, L. A.; Bery, J. W. J. Am Chem. Soc. 1957, 79,1482

9. Ciufolini, M. A.: Byne, N. E. J. Am. Chem. Soc. 1991, 113,8016.

10. (a) Hoeve, W. T.; Wynberg, H. J. Org. Chem $1980,45,2930$. (b) Dixon, G. M.; Halton, B. Eur. J. Org. Chem. 2004, 3707.

11. (a) Tin, T.-S.; Lilu, L.-B.: Zhao, Y: Li, T.-S. Sinth. Commm 2005, 35, 1859. (b) Muthusany, S.: Anlananda, S.; Gunanathan, C. Tetrahedron Lett. 2003, 13, 3931 . (c) Engemeie, G. H.; Ali, A. A. Sinth. Communt 2002,32, 253

12. (a) Tilichenko, M. N.; Visotskii, V. I. Zh. Obshch. Khint. 1962, 32, 84: English translation J. Gen. Chem. USSR 1962, 81. (b) Zymalkowski, F.; Kothari, M. Arch. Pham. (Weinhein) 1970 . 303, 667. (c) Oripov, E.; Shakhidoyatov, Kh. M.: Kadyrov, Ch. Sh.; Abdullaev, N. D. Khm. Geferosikl. Soedin. 1979, 5,684 . (d) Dammertz, W. Raimann, E. Arth. Pham. (Weinheim) 1977, 310, 172. (e) Thumunel, R. P.: Lefoulon, F.: Cantu, D.: Mahadevan, M. J. Org. Chem 1984, 19. 2208. (f) Lee, S. H.: Kim, S. I. Park, I. G.; Lee, E. S. Talung, Y. Heterocictes 2001, 55, 1555.

13. (a) Thummel, R. P. Lefoulon, F. J. Org. Chem. 1985, 50, 666. (b) Thunmel, R. P.; Lefoulon, F.; Mahadevan, R. J. Org. (Them. 1985, 50, 3824. (c) Thunmel, R. P., Jalung, Y. J. Org. (hem. 1985, 50,2407 .

14. (a) Tain, M. P.; Gupta, V. N.: Atal, C. K: Nath, L. G. D. Ind. J. Chent 1985, 24B, 983. (b) Chang, H. W. Kim, S. I.; Jung, H.; Talung, Y. Heterocycles 2003, 60, 1359 . (c) Lee, E. S. Park, T. G. Kim, S. I.; Jalu1g, Y. Heterocycles 2006, 61, 151 (d) Liu, T.-F.: Wilson, C. T.: Ye, P.; Spragule, K.; Sargent, K. Beletskv, Y: Si, G.: Yohannes, D; Ng, S.-C. Bioorg. Afed Chem. Lett. 2006, I6, 686

15. (a) Dhar, D. N.: Barton, D. The Chemistry of Chalcones and Related Componds; John Wilev \& Sons: 1981; p 8. (b) Gall, E. L.; Texier-Boullet, F.: Hamelin, J. Swth. Conmmm. 1999, 29, 3651 .

16. (a) Geissman, T. A. Clinton, R. O.J.Am Chem Soc 1946, 68,
697. (b) Sinistierra. I. V.: Garcia-Raso, A: Cábello, I. A: Marinas, I. M. Synthesis 1984, 6,502. (c) Lin, T.: Cromwell, N. H.: Kingsbury, C. A. J. Heteroncl. Chem 1985, 22, 21. (d) Fringuelli, F.; Pani, F. G.; Piematti, O.; Pizz, F. Tetrohedron 1994, 50, 11499. (e) Gupta, R.; Gupta, A. K. Paul, S.; Kachroo, P. L. Indian J. Chem. Sec. B 1995, 34, 61. (f) Vatsadze, S. Z: Mandenkova, M. A.: Sviridenkova, N. V.: Zvk. N. V: Krutko. D. P.; Churakov, A. V.; Antipin, M. Yu.; Howard, I. A. K.; Lange, H. Russ. Chem. Bull. 2006, 55,1184

17. (a) Schriner L : Kurosawa, T. J . Am. Chem. Soc 1930, $52,2538$. (b) Dhar, D. N.; Lal, J. B. J. Org. Chem. 1958, 23, 1159. (c) Hathaway, B. A.J. Chem. Edt. $1987,64,367$.

18. Irie, K.; Watanabe, K. Bull. Chent. Soc, Jpm. 1980, $53,1366$.

19. (a) Nakano, T.: Irifune, S. J.: Umano, S.: Inada, A.: Ishii, Y:; Ogawa, M. J. Om. Chem 1987, 52, 2239. (b) Nakano, T:; Migita. T. Chem. Lett 1993, 12,2157. (c) Bao, W. Zhang, Y.; Ying, T. Syth. Commun. 1996, 26, 503. (d) Zheng, M.; Wang, L.; Shao, J.: Zhong, Q. Synth. Conmm 1997, 27, 351. (e) Irampoor, N.; Kazemi, F. Tetrahedron 1998, 54, 9475. (f) Irampoor, N.: Zeynizadeh. B.: Aghapour, A. J. Chem. Res., Swop. 1999, 9, 554. (g) Dewa, T.; Saiki, T. Y. Aownta, J. An. Chent. Soc 2001, 123, 502. (h) Yadav, J. S.; Reddy, B. V. S.; Nagaraju, A.: Sarma, J. A. R. P. Smth. Commm 2002, $32,893$. (i) Salehi. P.: Khodaei, M. M.: Zolfigol, M. A.: Keyvan. A. Montatsh. Chent 2002, 133, 1291. (j) Zhang, X; Fan, X.; Niu, H. Wang, J. Green Chemistry 2003, 5, 267. (k) Huang, D. F.; Wang, I. X.; Hu, Y. L. Chin. Chem. Lett. 2003, 14,333 . (1) Deng, G.: Ren. T. Swm Conmm 2003, 33. 2995. (m) Sabitha, G.: Reddy, G. S. K. K.; Reddy, K. B.; Yadav, J. S. Sythesis 2004, 263. (n) Zhu, Y: Pan, Y. Chent Lett 2004, 33, 668 (o) Hu, Z. G.; Liu, T; Zeng, P. L.; Dong, Z. B. J. Chent. Res., Swop. 2004, l, 55. (p) Wang. L.: Sheng. T.; Tian, H.; Han, T.; Fan, Z.; Qian, C. Sw the sis 2004, 3060 (q) Cao, Y.-Q: Zhi, D.: Zhang, R; Chen, B.-H. Swht Common. 2005, 35, 1045. (r) Das, B.; Thirupathi, P.; Mahender, I; Reddy, K. R. I. Hol Cat A: Chem. 2006, 2t7, 182. (s) Anold, A.: Markert, M.; Mahrwald, R. Symthesis 2006, 7, 1099

20. (a) Babu, G.; Perumal, P. T. Sinth. Conmm, 1997, 27, 3677. (b) Wang, T.X; Kang, L ; Hu, Y; Wei, B. G. Synth. Commth. 2002, 32,1691 .

21. (a) Mayer, R. Chem Ber. 1955, 88, 1853 , (b) Tilichenko, M. N.; Barbulescu, E.; Barbuleseu, N. Rev? Chim. (Bucharest, Romania) $1961,12,631$ (C.4 57:55844)

22. (a) Paterson, I. Tetrhitedron 1988, H4 4207. (b) Murakaiyama, T.; Banno, K.: Narasaka, K. J. Am. Chem. Soc. 1974, 96,7503.

23. Smith, R. A.: Spencer, T. A. J. Org. Chem 1970, 35, 3220.

24. Birkofer, L.; Kim, S. M.; Engels, H. E. Ber: 1962, $96,1495$.

25. Wittig, G.; Hesse, A. Org. Sint. 1970, 50,66

26. House, H. O.: Crumrine, O. S.: Teranishi, A. Y.; Olmstead, H. D. J. Am. Chem. Soc. 1973, 95, 3310 .

27. Ralman, M. A. F. M.: Teong. B. S.: Kim, D. H.; Park, I. K.: Lee, E. S.; Tahng, Y. Tetruhedron 2007, 63, 2426

28. Reeve, W: Kiehlmann, E. J. Org. Chemt 1966, 31, 2164.

29. Yan, C.-G.: Cai, X.-M.: Wang, Q.-F.: Wang, T.-Y.: Zheng, M. Ong Biomol Chem. 2007, 5, 945

30. (a) List, B.; Lemer, R. A.; Barbas III, C. F. J. Ant. Chem. Soc. 2000, 122,2395 (b) Northrup, A. B.; MacMillar1, D. W. C. $J$. Am. Chem. Soc 2002, 127,6798 (c) Alcaide, B.; Almendros, P. Angew: Chem. Int Ed. 2003, 12,858

31. Buonora, P. T.; Rosauer, K. G.; Dai, L. Tetrahedron Lett. 1995, 36,4009

32. (a) Dubois, T. E.: Dubois, M. Compt. Rend. 1963, 256, 715. (b) Watson, P. L.: Bergman, R. G. J. Am. Chem. Soc. 1979, 101, 2055.

33. Edgar, O. B.: Johnson, D. H. J. Chem. Soc. 1958, 3925.

34 Tubul, A.; Santelli, M. Tetrhhedron 1988, 44, 3975.

35. Kaup, G.; Frey, H, Behmant, G. Chem. Ber, 1988, 121, 2127.

36. English, Ir. J.: Lamberti, V. J. Am. Chem. Soc. 1952, 7. 1909 